\title{
Cohnella thailandensis sp. nov., a xylanolytic bacterium from Thai soil
}

\author{
Saowapar Khianngam, ${ }^{1}$ Somboon Tanasupawat, ${ }^{1}$ \\ Ancharida Akaracharanya, ${ }^{2}$ Kwang Kyu Kim, ${ }^{3}$ Keun Chul Lee ${ }^{3}$ \\ and Jung-Sook Lee ${ }^{3}$
}

Correspondence

Somboon Tanasupawat

Somboon.T@chula.ac.th

Jung-Sook Lee

jslee@kribb.re.kr

\author{
${ }^{1}$ Department of Microbiology, Faculty of Pharmaceutical Sciences, Chulalongkorn University, \\ Bangkok 10330, Thailand \\ ${ }^{2}$ Department of Microbiology, Faculty of Science, Chulalongkorn University, Bangkok 10330, \\ Thailand \\ ${ }^{3}$ Korean Collection for Type Cultures, Biological Resource Center, Korea Research Institute of \\ Bioscience and Biotechnology, Yuseong, Daejeon 305-806, Republic of Korea
}

\begin{abstract}
A xylanolytic bacterium, strain $\mathrm{S} 1-3^{\top}$, was isolated from soil collected in Nan province, Thailand. It was characterized taxonomically based on phenotypic characteristics and 16S rRNA gene sequence comparison. The strain was a Gram-stain-positive, facultatively anaerobic, sporeforming, rod-shaped bacterium. It contained meso-diaminopimelic acid in the cell-wall peptidoglycan. The major menaquinone was MK-7. Iso- $\mathrm{C}_{16: 0}(39.5 \%)$ and anteiso- $\mathrm{C}_{15: 0}$ (26.8\%) were predominant cellular fatty acids. Diphosphatidylglycerol, phosphatidylglycerol, phosphatidylethanolamine and lysyl-phosphatidylglycerol were the major polar lipids. The DNA $\mathrm{G}+\mathrm{C}$ content was $53.3 \mathrm{~mol} \%$. Phylogenetic analysis using $16 \mathrm{~S}$ rRNA gene sequences showed that strain $S 1-3^{\top}$ was affiliated to the genus Cohnella, and was closely related to Cohnella ginsengisoli GR21-5 ${ }^{\top}$ and Cohnella thermotolerans CCUG $47242^{\top}$ with 95.7 and $95.3 \%$ sequence similarity, respectively. Strain $S 1-3^{\top}$ could be clearly distinguished from related species of the genus Cohnella by its physiological and biochemical characteristics as well as by its phylogenetic position. Therefore, the strain represents a novel species of the genus Cohnella, for which the name Cohnella thailandensis sp. nov. is proposed. The type strain is $\mathrm{S} 1-3^{\top}$ (=KCTC $22296^{\top}=$ TISTR $1890^{\top}=$ PCU $306^{\top}$ ).
\end{abstract}

The genus Cohnella was proposed by Kämpfer et al. (2006) and the type species is Cohnella thermotolerans. Members of the genus Cohnella are Gram-positive, endospore-forming, aerobic, rod-shaped organisms. At the time of writing, the genus Cohnella contains eight species, Cohnella thermotolerans isolated from a sample of industrial starch production in Sweden, Cohnella hongkongensis from a Chinese patient with neutropenic fever, Cohnella laeviribosi from a volcanic area in Likupang, Indonesia, Cohnella phaseoli from root nodules of Phaseolus coccineus in Spain, Cohnella fontinalis from fresh water in Japan, Cohnella luojiensis from soil of a Euphrates poplar forest in Xinjiang, China, and Cohnella yongneupensis and Cohnella ginsengisoli from wetland and ginseng soils in Korea, respectively (Teng et al., 2003; Kämpfer et al., 2006; Cho et al., 2007; García-Fraile et al.,

The GenBank/EMBL/DDBJ accession number for the 16S rRNA gene sequence of strain $\mathrm{S} 1-3^{\top}$ is FJ001840.

Neighbour-joining and maximum-parsimony trees based on 16S rRNA gene sequences, and the polar lipid profile of strain $\mathrm{S} 1-3^{\top}$, are available with the online version of this paper.
2008; Shiratori et al., 2010; Cai et al., 2010; Kim et al., 2010). In this paper, we describe the characterization of a novel xylanase-producing bacterium belonging to the genus Cohnella by means of a polyphasic taxonomic study.

Strain $51-3^{T}$ was isolated from a soil sample collected in Muang district, Nan province, Thailand, by the spread plate method on XC agar medium [containing $\left(\mathrm{l}^{-1}\right): 10 \mathrm{~g}$ oat spelt xylan, $5 \mathrm{~g}$ peptone, $1 \mathrm{~g}$ yeast extract, $4 \mathrm{~g} \mathrm{~K}_{2} \mathrm{HPO}_{4}$, $1 \mathrm{~g} \mathrm{MgSO}_{4} .7 \mathrm{H}_{2} \mathrm{O}, 0.2 \mathrm{~g} \mathrm{KCl}, 0.02 \mathrm{~g} \mathrm{FeSO}_{4} .7 \mathrm{H}_{2} \mathrm{O}, 15 \mathrm{~g}$ agar; $\mathrm{pH}$ 7.0]. In this screening step, agar plates were incubated at $40{ }^{\circ} \mathrm{C}$ for 2 days. The xylanase-producing capacity of the cultures was detected by using a Congo red overlay method, as reported by Teather \& Wood (1982) and Ruijssenaars \& Hartsmans (2001). Isolates showing xylanase-producing capacity were transferred to $\mathrm{C}$ agar medium. This medium had the same composition as XC medium without the oat spelt xylan. Colonies grown on $\mathrm{C}$ agar medium were examined for their morphological and cultural characteristics, including cell shape, colony appearance, endospore formation and pigmentation, after 
Table 1. Differential characteristics of strain $\mathrm{S} 1-3^{\top}$ and related species of the genus Cohnella

Strains: $1, \mathrm{~S} 1-3^{\mathrm{T}} ; 2$, C. ginsengisoli GR21-5 ${ }^{\mathrm{T}} ; 3$, C. thermotolerans CCUG $47242^{\mathrm{T}}$; 4, C. yongneupensis $5 \mathrm{YN} 10-14^{\mathrm{T}} ; 5$, C. hongkongensis $\mathrm{HKU}^{\mathrm{T}}$. Data were obtained from this study unless otherwise indicated. All strains are positive for catalase, oxidase, growth at pH 7-9 and 30-40 ${ }^{\circ} \mathrm{C}$, hydrolysis of aesculin, and acid production from amygdalin, aesculin and glycogen, but negative for indole production, growth in $5 \% \mathrm{NaCl}$, hydrolysis of L-arginine, casein, DNA, Tween 80 and L-tyrosine, and acid production from Dadonitol, D-arabitol, L-arabitol, dulcitol, erythritol, D-fucose, gluconate, inositol, inulin, 2-ketogluconate, 5-ketogluconate, D-sorbitol, Lsorbose and D-tagatose. + , Positive; $\mathrm{W}$, weakly positive; - , negative.

\begin{tabular}{|c|c|c|c|c|c|}
\hline Characteristic & 1 & 2 & 3 & 4 & 5 \\
\hline \multicolumn{6}{|l|}{ Growth at/in: } \\
\hline $3 \% \mathrm{NaCl}$ & + & - & $\mathrm{w}$ & - & - \\
\hline pH 5 & $\mathrm{w}$ & + & $\mathrm{w}$ & + & - \\
\hline $\mathrm{pH} 6$ & + & + & + & + & - \\
\hline 10 and $15{ }^{\circ} \mathrm{C}$ & - & + & - & + & - \\
\hline 20 and $25^{\circ} \mathrm{C}$ & + & + & + & + & - \\
\hline 45 and $50{ }^{\circ} \mathrm{C}$ & + & - & + & - & + \\
\hline $55^{\circ} \mathrm{C}$ & - & - & + & - & + \\
\hline $60{ }^{\circ} \mathrm{C}$ & - & - & - & - & + \\
\hline Citrate utilization & - & $\mathrm{w}$ & - & - & - \\
\hline Nitrate reduction & - & + & - & - & + \\
\hline Urease activity & - & + & - & + & - \\
\hline \multicolumn{6}{|l|}{ Hydrolysis of: } \\
\hline Gelatin & + & - & + & - & - \\
\hline Starch & + & + & $\mathrm{w}$ & + & - \\
\hline \multicolumn{6}{|l|}{ Acid from: } \\
\hline $\mathrm{N}$-Acetylglucosamine & - & - & - & - & + \\
\hline D-Arabinose & $\mathrm{w}$ & - & + & - & - \\
\hline L-Arabinose & + & - & - & - & + \\
\hline Arbutin & + & + & - & - & + \\
\hline Cellobiose & + & + & - & - & + \\
\hline D-Fructose & + & + & + & - & + \\
\hline L-Fucose & + & - & - & - & - \\
\hline D-Galactose & + & - & + & - & + \\
\hline Gentiobiose & + & + & - & - & + \\
\hline Glucose & + & + & - & - & + \\
\hline$\alpha$-Glucopyranoside & + & - & - & - & + \\
\hline Glycerol & - & + & - & + & - \\
\hline Lactose & + & + & - & + & + \\
\hline D-Lyxose & - & - & + & - & - \\
\hline Maltose & + & + & - & - & + \\
\hline D-Mannitol & + & + & - & - & + \\
\hline D-Mannose & + & + & - & - & + \\
\hline$\alpha$-Mannopyranoside & - & - & + & - & - \\
\hline Melibiose & + & + & - & - & + \\
\hline Melezitose & + & - & - & - & - \\
\hline Raffinose & + & + & - & - & + \\
\hline L-Rhamnose & + & - & - & - & - \\
\hline D-Ribose & + & + & + & - & - \\
\hline Salicin & + & + & - & - & + \\
\hline Sucrose & + & + & - & - & - \\
\hline Starch & + & + & + & - & + \\
\hline Trehalose & + & + & - & - & + \\
\hline
\end{tabular}

Table 1. cont.

\begin{tabular}{|lccccc|}
\hline Characteristic & $\mathbf{1}$ & $\mathbf{2}$ & $\mathbf{3}$ & $\mathbf{4}$ & $\mathbf{5}$ \\
\hline Turanose & + & + & + & - & - \\
Xylitol & - & - & + & - & - \\
D-Xylose & + & + & - & - & + \\
L-Xylose & - & - & + & - & - \\
$\beta$-Xylopyranoside & + & + & + & - & $\mathrm{w}$ \\
DNA G+C content & 53.3 & $61.3^{*}$ & $59.0 \dagger$ & $58.8^{*}$ & $60.9 \dagger$ \\
$($ mol\%) & & & & & \\
\hline
\end{tabular}

${ }^{\star}$ Data from Kim et al. (2010).

$\dagger$ Data from Kämpfer et al. (2006).

incubation at $37{ }^{\circ} \mathrm{C}$ for 2 days. Motility was observed under a phase-contrast microscope (Eclipse 80i; Nikon). Tests for catalase, oxidase and urease activity, hydrolysis of aesculin, L-arginine, casein, DNA, gelatin, starch, Tween 80 and L-tyrosine, the methyl red/Voges-Proskauer reactions, indole production, nitrate reduction, citrate utilization and hydrogen sulfide $\left(\mathrm{H}_{2} \mathrm{~S}\right)$ production were performed as described by Barrow \& Feltham (1993). Additional biochemical characteristics were recorded after 2 days of incubation in API $50 \mathrm{CH}$ strips. Growth under anaerobic conditions on agar plates was investigated by using a Gaspak (BBL) anaerobic jar. Growth at different $\mathrm{pH}(5,6$, 7, 8 and 9), in 3 and $5 \%(\mathrm{w} / \mathrm{v}) \mathrm{NaCl}$ and at different temperatures $\left(10,15,20,25,30,40,45,50,55\right.$ and $\left.60{ }^{\circ} \mathrm{C}\right)$ was tested by using $\mathrm{C}$ agar medium. All tests were carried out by incubating the cultures at $37{ }^{\circ} \mathrm{C}$, except for investigations into the effect of temperature on growth.

Detection of menaquinones and the cell-wall diamino acid was performed as described by Komagata \& Suzuki (1987). For total cellular fatty acid analysis, cells were cultivated on TSA for 2 days at $30{ }^{\circ} \mathrm{C}$, and fatty acid methyl esters were extracted and prepared according to the standard protocol of the MIDI/Hewlett Packard Microbial Identification System (Sasser, 1990). Polar lipids were extracted, examined by two-dimensional TLC and identified by using published procedures (Minnikin et al., 1977).

DNA was prepared by the method of Saito \& Miura (1963). DNA base composition was determined by reversed-phase HPLC (Tamaoka \& Komagata, 1984). The 16S rRNA gene of the novel strain was amplified, and the PCR product was purified and sequenced as described previously (Tanasupawat et al., 2004). The sequence of strain $S 1-3^{\mathrm{T}}$ (1531 bp) was aligned with selected sequences obtained from GenBank by using CLUSTAL $x$ version 1.83 (Thompson et al., 1997). The alignment was edited manually to remove gaps and ambiguous nucleotides prior to the reconstruction of phylogenetic trees. Phylogenetic trees were reconstructed by using the neighbour-joining (Saitou \& Nei, 1987) and maximumparsimony (Fitch, 1971) methods with MEGA4 software (Tamura et al., 2007). Confidence values of branches of the phylogenetic trees were determined by using bootstrap analyses (Felsenstein, 1985) based on 1000 resamplings. 
Strain $\mathrm{S} 1-3^{\mathrm{T}}$ was a Gram-stain-positive, facultatively anaerobic, motile, rod-shaped bacterium. Subterminal ellipsoidal endospores were observed in swollen sporangia. After 2 days of incubation on C medium, colonies were $0.5-1.0 \mathrm{~mm}$ in diameter, circular, flat and white. The phenotypic characteristics are listed in the species description and in Tables 1 and 2. In the $16 \mathrm{~S}$ rRNA gene-based phylogenetic tree reconstructed according to the neighbour-joining method, S1- $3^{\mathrm{T}}$ was placed in a monophyletic cluster consisting of all known species of the genus Cohnella, as shown in Fig. 1. Trees reconstructed by the neighbour-joining and maximum-parsimony methods, including strain $S 1-3^{\mathrm{T}}$ and all species of the genera Cohnella and Paenibacillus, are shown as Supplementary Figs S1 and S2 (available in IJSEM Online). Strain $\mathrm{S} 1-3^{\mathrm{T}}$ was closely related to $C$. ginsengisoli GR21-5 ${ }^{\mathrm{T}}$ (95.7\%), C. thermotolerans CCUG $47242^{\mathrm{T}}$ (95.3\%), C. yongneupensis $5 \mathrm{YN} 10-14^{\mathrm{T}}(94.6 \%), C$. hongkongensis HKU3 $^{\mathrm{T}}$ (94.2\%), C. laeviribosi RI-39 ${ }^{\mathrm{T}}$ (94.0\%), C. luojiensis HY-22R ${ }^{\mathrm{T}}(93.8 \%)$, C. phaseoli $\mathrm{GSPCl}^{\mathrm{T}}(93.5 \%)$ and $C$. fontinalis $\mathrm{YT}-1101^{\mathrm{T}}(93.5 \%)$ based on $16 \mathrm{~S}$ rRNA gene sequence similarity. The low 16S rRNA gene sequence similarity $(93.5-95.7 \%)$ of strain $S 1-3^{\mathrm{T}}$ with respect to related type strains was below the recommended range of 98.7-99.0\% where DNA-DNA reassociation experiments should be mandatory (Stackebrandt \& Ebers, 2006). The DNA G + C content was $53.3 \mathrm{~mol} \%$, which was close to the values

Table 2. Cellular fatty acid composition (\%) of strain $S 1-3^{\top}$ and related species of the genus Cohnella

Strains: $1, \mathrm{~S} 1-3^{\mathrm{T}} ; 2$, C. ginsengisoli GR21-5 ${ }^{\mathrm{T}} ; 3$, C. thermotolerans CCUG $47242^{\mathrm{T}}$; 4, C. yongneupensis $5 \mathrm{YN} 10-14^{\mathrm{T}} ; 5$, C. hongkongensis HKU $^{\mathrm{T}}$. Data were obtained in this study. ND, Not detected; tr, $<1.0$.

\begin{tabular}{|c|c|c|c|c|c|}
\hline Fatty acid & 1 & 2 & 3 & 4 & 5 \\
\hline \multicolumn{6}{|c|}{ Straight-chain saturated } \\
\hline $\mathrm{C}_{10: 0}$ & ND & $\mathrm{ND}$ & $\operatorname{tr}$ & ND & $\operatorname{tr}$ \\
\hline $\mathrm{C}_{12: 0}$ & ND & ND & $\operatorname{tr}$ & ND & 1.6 \\
\hline $\mathrm{C}_{14: 0}$ & 1.8 & 5.5 & 1.5 & 2.3 & 8.4 \\
\hline $\mathrm{C}_{15: 0}$ & 5.2 & 1.5 & 1.1 & 1.7 & $\operatorname{tr}$ \\
\hline $\mathrm{C}_{16: 0}$ & 7.7 & 16.2 & 6.8 & 10.2 & 29.6 \\
\hline$C_{17: 0}$ & $\operatorname{tr}$ & $\mathrm{ND}$ & ND & ND & ND \\
\hline \multicolumn{6}{|c|}{ Branched saturated } \\
\hline iso- $\mathrm{C}_{11: 0}$ & $\operatorname{tr}$ & ND & $\mathrm{ND}$ & ND & ND \\
\hline iso- $\mathrm{C}_{12: 0}$ & ND & $\mathrm{ND}$ & ND & $\operatorname{tr}$ & ND \\
\hline iso- $\mathrm{C}_{14: 0}$ & 4.4 & 3.8 & 3.4 & 2.1 & 1.2 \\
\hline iso- $\mathrm{C}_{15: 0}$ & 7.5 & 9.2 & 4.4 & 1.3 & 5.1 \\
\hline iso- $\mathrm{C}_{16: 0}$ & 39.5 & 18.9 & 48.3 & 20.8 & 11.2 \\
\hline iso- $\mathrm{C}_{17: 0}$ & 1.9 & 1.2 & 1.1 & ND & 5.6 \\
\hline anteiso- $\mathrm{C}_{11: 0}$ & $\operatorname{tr}$ & ND & ND & ND & $\operatorname{tr}$ \\
\hline anteiso- $\mathrm{C}_{13: 0}$ & ND & ND & ND & 2.0 & $\operatorname{tr}$ \\
\hline anteiso- $\mathrm{C}_{15: 0}$ & 26.8 & 40.8 & 26.9 & 51.1 & 27.1 \\
\hline anteiso- $\mathrm{C}_{17: 0}$ & 3.8 & 2.9 & 4.8 & 6.9 & 10.0 \\
\hline \multicolumn{6}{|l|}{ Unsaturated } \\
\hline $\mathrm{C}_{16: 1} \omega 7 c$ alcohol & $\mathrm{ND}$ & $\mathrm{ND}$ & $\operatorname{tr}$ & $\operatorname{tr}$ & ND \\
\hline $\mathrm{C}_{16: 1} \omega 11 c$ & ND & $\mathrm{ND}$ & $\operatorname{tr}$ & $\operatorname{tr}$ & ND \\
\hline $\mathrm{C}_{17: 1} \omega 6 c$ & $\mathrm{ND}$ & ND & $\operatorname{tr}$ & ND & ND \\
\hline
\end{tabular}

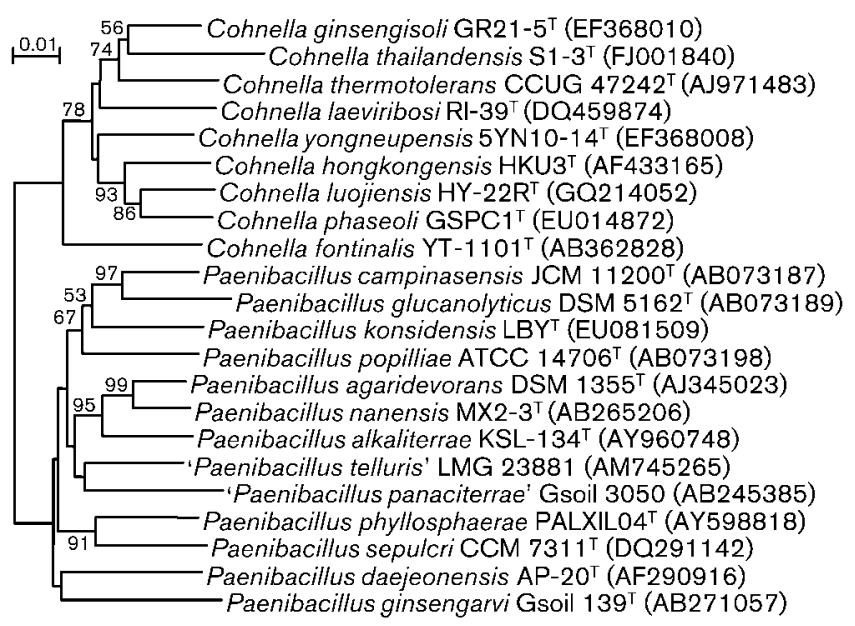

Fig. 1. Neighbour-joining tree based on $16 \mathrm{~S}$ rRNA gene sequences showing the phylogenetic position of strain $S 1-3^{\top}$ among all species of the genus Cohnella and selected species of the genus Paenibacillus. Based on 1000 replications, bootstrap percentages above $50 \%$ are shown. Bar, 0.01 substitutions per nucleotide position.

observed for other members of the genus Cohnella (Kämpfer et al., 2006; Yoon et al., 2007). Strain S1-3 $3^{\mathrm{T}}$ contained iso- $\mathrm{C}_{16: 0}$ $(39.5 \%)$ and anteiso- $\mathrm{C}_{15: 0}(26.8 \%)$ as the predominant cellular fatty acids. Strain $\mathrm{S} 1-3^{\mathrm{T}}$, C. ginsengisoli $\mathrm{GR} 21-5^{\mathrm{T}}, C$. thermotolerans CCUG $47242^{\mathrm{T}}$, C. yongneupensis $5 \mathrm{YN} 10-14^{\mathrm{T}}$ and C. hongkongensis $\mathrm{HKU}^{\mathrm{T}}$ showed similar cellular fatty acid profiles, but significant quantitative differences were also found, as shown in Table 2. Strain S1-3 ${ }^{\mathrm{T}}$ contained mesodiaminopimelic acid in the cell-wall peptidoglycan. The major menaquinone was MK-7. Major polar lipids were diphosphatidylglycerol, phosphatidylglycerol, phosphatidylethanolamine and lysyl-phosphatidylglycerol (Supplementary Fig. S3).

The physiological and biochemical characteristics and DNA $G+C$ contents that differentiate strain $S 1-3^{\mathrm{T}}$ from other species of the genus Cohnella are listed in Table 1. It should be noted that, in contrast to C. ginsengisoli GR21$5^{\mathrm{T}}$, C. thermotolerans CCUG $47242^{\mathrm{T}}$, C. yongneupensis $5 \mathrm{YN} 10-14^{\mathrm{T}}$ and $C$. hongkongensis $\mathrm{HKU}^{\mathrm{T}}{ }^{\mathrm{T}}$, strain $\mathrm{S} 1-3^{\mathrm{T}}$ was able to grow in $3 \% \mathrm{NaCl}$ and at $50{ }^{\circ} \mathrm{C}$ and to produce acid from many carbohydrates. On the basis of its phenotypic characteristics and its phylogenetic position, the strain represents a novel species of the genus Cohnella, for which the name Cohnella thailandensis sp. nov. is proposed.

\section{Emended description of the genus Cohnella Kämpfer et al. 2006 emend. García-Fraile et al. 2008}

The description is as given by Kämpfer et al. (2006) and García-Fraile et al. (2008) with the following amendments. Cells are aerobic or facultatively anaerobic and stain Grampositive or Gram-negative. Some species grow at 10 or $60{ }^{\circ} \mathrm{C}$. Some species grow in the presence of $3 \% \mathrm{NaCl}$. The diamino acid in the cell-wall hydrolysates is meso-diaminopimelic acid. The DNA G + C content ranges from 49.6 to $61.3 \mathrm{~mol} \%$. 


\section{Description of Cohnella thailandensis sp. nov.}

Cohnella thailandensis (thai.lan.den'sis. N.L. fem. adj. thailandensis pertaining to Thailand, where the type strain was isolated).

Cells of strain $51-3^{\mathrm{T}}$ are Gram-stain-positive, facultatively anaerobic, motile rods $(0.2-0.5 \times 1.2-2.5 \mu \mathrm{m})$. Subterminal ellipsoidal endospores are observed in swollen sporangia. Colonies are $0.5-1.0 \mathrm{~mm}$ in diameter, circular, flat and white after 2 days of incubation on $\mathrm{C}$ agar medium. Grows at $\mathrm{pH} 5$ (weakly), pH 6-9 (optimally at 7), $20-50{ }^{\circ} \mathrm{C}$ (optimally at $37^{\circ} \mathrm{C}$ ), in $3 \% \mathrm{NaCl}$ and under anaerobic conditions. Does not grow in $5 \% \mathrm{NaCl}$ and at $10,15,55$ and $60{ }^{\circ} \mathrm{C}$. Positive for catalase (weakly), oxidase, hydrolysis of aesculin, gelatin and starch, but negative for methyl-red and Voges-Proskauer reactions, nitrate reduction, indole production, citrate utilization, $\mathrm{H}_{2} \mathrm{~S}$ production, urease and hydrolysis of Larginine, casein, DNA, Tween 80 and L-tyrosine. Able to produce acid from D-arabinose (weakly), amygdalin, Larabinose, arbutin, cellobiose, aesculin, D-fructose, L-fucose, D-galactose, gentiobiose, glucose, $\alpha$-glucopyranoside, glycogen, lactose, maltose, D-mannitol, D-mannose, melibiose, melezitose, raffinose, L-rhamnose, D-ribose, salicin, sucrose, starch, trehalose, turanose, $\mathrm{D}$-xylose and $\beta$-xylopyranoside, but not from $\mathrm{N}$-acetylglucosamine, D-adonitol, D-arabitol, Larabitol, dulcitol, erythritol, D-fucose, gluconate, 2-ketogluconate, 5-ketogluconate, glycerol, inositol, inulin, D-lyxose, $\alpha$-mannopyranoside, D-sorbitol, L-sorbose, D-tagatose, xylitol or L-xylose. MK-7 is the predominant menaquinone. The predominant fatty acids are iso- $\mathrm{C}_{16: 0}$ and anteiso- $\mathrm{C}_{15: 0}$. The diamino acid in the cell-wall hydrolysate is meso-diaminopimelic acid. Major polar lipids are diphosphatidylglycerol, phosphatidylglycerol, phosphatidylethanolamine and lysylphosphatidylglycerol. The DNA G $+\mathrm{C}$ content of the type strain is $53.3 \mathrm{~mol} \%$.

The type strain is $\mathrm{S} 1-3^{\mathrm{T}}\left(=\right.$ KCTC $22296^{\mathrm{T}}=$ TISTR $1890^{\mathrm{T}}$ $=$ PCU $306^{\mathrm{T}}$ ), isolated from a soil sample collected in Muang district, Nan province, Thailand.

\section{Acknowledgements}

The Government Research Grant, Chulalongkorn University (2005), the scholarship from the Royal Golden Jubilee Ph. D. Program (2007) to S. K. and a grant from KRIBB Research Initiative Program are gratefully acknowledged.

\section{References}

Barrow, G. I. \& Feltham, R. K. A. (1993). Cowan and Steel's Manual for the Identification of Medical Bacteria, 3rd edn. Cambridge: Cambridge University Press.

Cai, F., Wang, Y., Qi, H., Dai, J., Yu, B., An, H., Rahman, E. \& Fang, C. (2010). Cohnella luojiensis sp. nov., isolated from soil of a Euphrates poplar forest. Int J Syst Evol Microbiol 60, 1605-1608.

Cho, E.-A., Lee, J.-S., Lee, K. C., Jung, H.-C., Pan, J.-G. \& Pyun, Y.-R. (2007). Cohnella laeviribosi sp. nov., isolated from a volcanic pond. Int J Syst Evol Microbiol 57, 2902-2907.
Felsenstein, J. (1985). Confidence limits on phylogenies: an approach using the bootstrap. Evolution 39, 783-791.

Fitch, W. M. (1971). Toward defining the course of evolution: minimum change for a specific tree topology. Syst Zool 20, 406-416.

García-Fraile, P., Velázquez, E., Mateos, P. F., Martínez-Molina, E. \& Rivas, R. (2008). Cohnella phaseoli sp. nov., isolated from root nodules of Phaseolus coccineus in Spain, and emended description of the genus Cohnella. Int J Syst Evol Microbiol 58, 1855-1859.

Kämpfer, P., Rosselló-Mora, R., Falsen, E., Busse, H.-J. \& Tindall, B. J. (2006). Cohnella thermotolerans gen. nov., sp. nov., and classification of 'Paenibacillus hongkongensis' as Cohnella hongkongensis sp. nov. Int J Syst Evol Microbiol 56, 781-786.

Kim, S.-J., Weon, H.-Y., Kim, Y.-S., Anandham, R., Jeon, Y.-A., Hong, S.-B. \& Kwon, S.-W. (2010). Cohnella yongneupensis sp. nov. and Cohnella ginsengisoli sp. nov., isolated from two different soils. Int J Syst Evol Microbiol 60, 526-530.

Komagata, K. \& Suzuki, K. (1987). Lipid and cell-wall analysis in bacterial systematics. Methods Microbiol 19, 161-207.

Minnikin, D. E., Patel, P. V., Alshamaony, L. \& Goodfellow, M. (1977). Polar lipid composition in the classification of Nocardia and related bacteria. Int J Syst Bacteriol 27, 104-117.

Ruijssenaars, H. J. \& Hartsmans, S. (2001). Plate screening methods for the detection of polysaccharase-producing microorganisms. Appl Microbiol Biotechnol 55, 143-149.

Saito, H. \& Miura, K. (1963). Preparation of transforming deoxyribonucleic acid by phenol treatment. Biochim Biophys Acta 72, 619-629.

Saitou, N. \& Nei, M. (1987). The neighbor-joining method: a new method for reconstructing phylogenetic trees. Mol Biol Evol 4, 406-425.

Sasser, M. (1990). Identification of bacteria by gas chromatography of cellular fatty acids, MIDI Technical Note 101. Newark, DE: MIDI Inc.

Shiratori, H., Tagami, Y., Beppu, T. \& Ueda, K. (2010). Cohnella fontinalis sp. nov., a xylanolytic bacterium isolated from fresh water. Int J Syst Evol Microbiol 60, 1344-1348.

Stackebrandt, E. \& Ebers, J. (2006). Taxonomic parameters revisited: tarnished gold standards. Microbiol Today 33, 152-155.

Tamaoka, J. \& Komagata, K. (1984). Determination of DNA base composition by reversed-phase high-performance liquid chromatography. FEMS Microbiol Lett 25, 125-128.

Tamura, K., Dudley, J., Nei, M. \& Kumar, S. (2007). MEGA4: molecular evolutionary genetics analysis (MEGA) software version 4.0. Mol Biol Evol 24, 1596-1599.

Tanasupawat, S., Thawai, C., Yukphan, P., Moonmangmee, D., Itoh, T., Adachi, O. \& Yamada, Y. (2004). Gluconobacter thailandicus sp. nov., an acetic acid bacterium in the $\alpha$-Proteobacteria. J Gen Appl Microbiol 50, 159-167.

Teather, R. M. \& Wood, P. J. (1982). Use of Congo red-polysaccharide interactions in enumeration and characterization of cellulolytic bacteria from the bovine rumen. Appl Environ Microbiol 43, 777-780.

Teng, J. L. L., Woo, P. C. Y., Leung, K. W., Lau, S. K. P., Wong, M. K. M. \& Yuen, K. Y. (2003). Pseudobacteraemia in a patient with neutropenic fever caused by a novel paenibacillus species: Paenibacillus hongkongensis sp. nov. Mol Pathol 56, 29-35.

Thompson, J. D., Gibson, T. J., Plewniak, F., Jeanmougin, F. \& Higgins, D. G. (1997). The CLUSTAL_X windows interface: flexible strategies for multiple sequence alignment aided by quality analysis tools. Nucleic Acids Res 25, 4876-4882.

Yoon, M.-H., Ten, L. N. \& Im, W.-T. (2007). Cohnella panacarvi sp. nov., a xylanolytic bacterium isolated from ginseng cultivating soil. J Microbiol Biotechnol 17, 913-918. 